\title{
BIOSYNTHETICAL CAPACITY OF KAEMPFEROL FROM IN VITRO PRODUCED ARGEL (SOLENOSTEMMA ARGEL (DEL.) HAYNE) CALLUS
}

\author{
${ }^{1}$ Mohamed R. Abd Alhady, ${ }^{1}$ Ghada A. Hegazi, ${ }^{1}$ Reda E. Abo El-Fadl , ${ }^{2 \# S a m a r ~ Y . ~ D e s o u k e y ~}$ \\ ${ }^{1}$ Tissue Culture Unit, Genetic Resources Department, Ecology and Dry Land Agriculture Division, \\ Desert Research Center, 11753 El-Matariya, 1 Mathaf El-Matariya St., Cairo, Egypt \\ ${ }^{2}$ Pharmacognosy Department, Faculty of Pharmacy, Minia University, 61519 Minia, Egypt
}

\begin{abstract}
Solenostemma argel (Del.) Hayne (family Asclepiadaceae) is an Egyptian natural perennial shrub. The study attempted to establish callus from $S$. argel and to investigate its biosynthetic potentiality to produce the flavonoid kaempferol, which has a wide range of pharmacological activities. Seeds and aerial parts were collected from naturally grown plants at Saint Catherine, Sinai. Callus from different explants of in vitro germinated seedlings (stem, leaf and root) was successfully initiated on Murashige and Skoog (MS) medium supplemented with each of 2,4-dichlorophenoxyacetic acid (2,4-D) and $\beta$ naphthalene acetic acid (NAA), separately, at concentrations of 1.0, 2.0 and $3.0 \mathrm{mg} / \mathrm{L}$, in addition to $0.5 \mathrm{mg} / \mathrm{L}$ kinetin (KIN). However, the fresh weights of leaf-derived callus were the highest. Casein hydrolysate $(\mathrm{CH})$ and yeast extract $(\mathrm{YE})$, as elicitors, at concentrations of $0.5,1.0$ and $2.0 \mathrm{~g} / \mathrm{L}$, were examined for elevating the in vitro production of kaempferol in callus cultures. The total methanol extracts of the aerial parts of wild plants, four-week-old in vitro germinated seedlings' explants and their derived callus were analyzed qualitatively and quantitatively for kaempferol, using HPLC. A significant difference in the content of kaempferol was observed. Callus produced from tested explants showed a capacity for production and accumulation of kaempferol. The highest concentration of kaempferol was in callus obtained from seedlings' stem explants on MS medium containing $1.0 \mathrm{mg} / \mathrm{L}$ 2,4-D and $0.5 \mathrm{mg} / \mathrm{L} \mathrm{KIN}$, in addition to $2.0 \mathrm{mg} / \mathrm{L} \mathrm{YE}$. In conclusion, $\mathrm{S}$. argel callus cultures showed a capacity for synthesizing kaempferol and could be an alternative renewable natural source for its large-scale production.
\end{abstract}

Keywords: Asclepiadaceae, in vitro, flavonoid, elicitor, casein hydrolysate, yeast extract

\section{INTRODUCTION}

Medicinal plants are the most exclusive natural source of life saving drugs for the majority of the world's population. Bioactive compounds currently extracted from plants are used as pharmaceuticals, food additives, pigments, dyes, insecticides, cosmetics, perfumes and fine chemicals, but unfortunately many are directed to extinction and should be conserved.

Solenostemma argel (Del.) Hayne (family Asclepiadaceae) is an Egyptian species, known as "Argal" or "Harghel" (El-Hadidi and Fayed, 1994), commonly growing in the Eastern Desert and along the Nile in South Egypt (Täckholm, 1974). It is a wild perennial shrub, with white flowers in auxiliary umbles, fruits ovate green-purple. S. argel leaves are used in Egyptian folk medicine as purgative, antipyretic, expectorant and as a remedy for bronchitis, for gastrointestinal cramps, stomach ache, colic, cold and urinary tract infections (Hegazi et al., 1994). In addition, this plant is used in herbal mixtures for the treatment of viral hepatitis B and C, as an immunostimulant and for hypercholesterolemia (Shawkat, 1997). Hegazi et al. (2006) investigated the hepatotoxic and nephrotoxic effect of $S$. argel. The plant also showed significant anti-cancer and antioxidant activities (Nassr-Allah et al., 2009 and Hanafi and Mansour, 2011)

Phytochemical investigations on $S$. argel have led to the isolation of compounds belonging to several classes of secondary metabolites, such as flavonoid glycosides (El-Askary, 2003 and Heneidak et al., 2006), monoterpenes (Kamel et al., 2000 and El-Askary, 2003), acylated phenolic glycosides (Kamel, 2003), pregnane and secopregnane glycosides 
(Hamed, 2001; Hassan et al., 2001; El-Askary, 2003; Plaza et al., 2003, 2004, 2005a \& b and Perrone et al., 2006]. The pharmacological studies on $S$. argel evidenced spasmolytic and anaesthetic (El-Tahir et al., 2005), fungitoxic (Abd El-Hady and Ouf, 1993 and Abd El-Hady et al., 1994a \& b) and antimicrobial activity against selected gram-positive and gramnegative bacteria (Hegazi et al., 1994 and Tharib et al., 1986). Topical anti-inflammatory activity of extracts of $S$. argel leaves were also reported (Innocenti et al., 2005). Pregnane and secopregnane glycosides isolated from this species have shown interesting antiproliferative activity (Plaza et al., 2005a \& b). Fifteen new 14,15-secopregnane glycosides, namely argelosides $\mathrm{A}-\mathrm{J}$, and nine new 15-ketopregnane glycosides, namely stemmosides $C-K$, have been isolated from the pericarps, hairy seeds and leaves (Perrone et al., 2008).

Kaempferol, kaempferol monoglycoside, and its derivatives, isolated along with other flavonoids from a preparation of the $S$. argel, were found to have a potent spasmolytic activity (Khalid et al., 1992). Kaempferol derivatives inhibited oedema by $30-40 \%$, these values were quite comparable to the activity of indomethacin $\quad(59 \%$ oedema reduction). This confirms and justifies the topical anti-inflammatory activity of this species in Egyptian folk medicine (Innocenti et al., 2005). Also, Shafek et al. (2012) investigated the antibacterial and antioxidant activities of two new kaempferol glycosides isolated from S. argel stem extract.

Kaempferol is a natural flavonoid that has been isolated from many plant sources. It is a yellow crystalline solid with a melting point 267-278 ${ }^{\circ} \mathrm{C}$. It is a strong antioxidant compound and helps to prevent oxidative damage of pure cells, lipids and DNA. It prevents arteriosclerosis by inhibiting the oxidation of low density lipoprotein and the formation of platelet in the blood; concomitantly it also inhibits the formation of cancer cell, thus meaning a reduced risk of developing several disorders such as cardiovascular diseases and cancer (Konam et al., 2012). Numerous preclinical studies have shown that kaempferol and some of its glycosides have a wide range of pharmacological activities, including antioxidant, anti-inflammatory, antimicrobial, anticancer, cardioprotective, neuroprotective, antidiabetic, anti-osteoporotic, estrogenic/antiestrogenic, anxiolytic, analgesic and antiallergic activities (Calderon-Montaño et al., 2011). Kaempferol consumption is correlated with a reduced lung cancer incidence (Irwin, 2008). It may be also a potent prophylactic against NOX-mediated neurodegeneration (Jang et al., 2011).

In general, plants produce very small quantities of secondary metabolites and their production may only occur under certain circumstances. However, in vitro culture techniques could be the alternatives for the mass production of these metabolites, which is not season dependent. The principle advantage of this technology is that it provides a continuous, reliable source of pure and natural plant pharmaceuticals on a large scale, where plant cell cultures give metabolites that are easily extracted (Abraham et al., 2011).

In plant tissue culture, accumulation of secondary metabolites could be enhanced by the treatment of various kinds of elicitors, which can be biotic and abiotic. Elicitors could be applied to unorganized plant cell and callus cultures for the production of specific compounds. They control the metabolism of receptive plant cells. Previous studies showed that the accumulation of different secondary metabolites can be efficiently induced by using elicitor (Ekiert and Gomolka, 2000 and Ekiert, 2001). Casein hydrolysate $(\mathrm{CH})$ and yeast extract (YE) are well known as complex mixtures of organic compounds that have been used in plant tissue culture due to their ability to induce and promote secondary metabolism (Marsik et al., 2014).

Callus cultures have been carried out in several plants for the production of flavonoids (Bharati and Bansal, 2014). However, few studies were found on the in vitro production of active compounds from S. argel. Amariei et 
al. (1991) tested the biosynthetical capacity of the active principles of in vitro regenerated $S$. argel callus and shoots and found that both the callus and shoots showed a capacity for synthesizing some medicinal compounds. Also, El-Tigani and Ahmed (2009) showed that in vitro cultured tissues of $S$. argel are capable to produce and accumulate alkaloids, cardinolides and flavonoids. The present study aimed to produce kaempferol through in vitro callus cultures of $S$. argel, and to determine its yield in the callus tissue. $\mathrm{CH}$ and YE as elicitors were examined for the enhancement of kaempferol production in callus cultures of $S$. argel.

\section{MATERIALS AND METHODS}

\section{Plant Material and Culture Conditions}

S. argel seeds were collected from mature plants grown naturally in Saint Catherine, Sinai. Seeds were washed under running tap water for $30 \mathrm{~min}$. Surface sterilization of seeds was carried out in a transfer hood by soaking them in a $50 \%(\mathrm{v} / \mathrm{v})$ Clorox bleach solution (2.5\% sodium hypochlorite) for $30 \mathrm{~min}$, providing gentle agitation, followed by three sequential rinses for one $\mathrm{min}$ in sterilized distilled water. All seeds were placed directly on the surface of full-strength Murashige and Skoog (MS) (Murashige and Skoog, 1962) medium (Duchefa, Haarlem, the Netherlands) supplemented with $100 \mathrm{mg} / \mathrm{L}$ myo-inositol and $30 \mathrm{~g} / \mathrm{L}$ sucrose. The $\mathrm{pH}$ of the medium was adjusted to 5.7-5.8 before being solidified with $3.0 \mathrm{~g} / \mathrm{L}$ phytagel (Duchefa, Haarlem, the Netherlands). Media were dispensed in large jars capped with autoclavable polypropylene lids, then autoclaved at a pressure of 1.06 $\mathrm{kg} / \mathrm{cm}^{2}$ and $121^{\circ} \mathrm{C}$ for $15 \mathrm{~min}$. The cultures were incubated at approximately $25 \pm 2^{\circ} \mathrm{C}$ with a 16-h photoperiod under cool white florescent tubes (F140t9d/38, Toshiba). Fourweek-old in vitro germinated seedlings of $S$. argel were used as sources of explants for initiation of callus cultures.

\section{Callus Initiation and Proliferation}

Leaves, stems and roots were excised from the seedlings of $S$. argel and cut into small pieces $(0.5-1 \mathrm{~cm})$, then cultured aseptically on solid MS medium supplemented with various plant growth regulators (Sigma Cell Culture, min. 90\%, St. Louis, USA). Naphthalene acetic acid (NAA) or dichlorophenoxy acetic acid (2,4-D), at concentrations of 1.0, 2.0 and 3.0 $\mathrm{mg} / \mathrm{L}$, as auxins, and kinetin (KIN), at a concentration of $0.5 \mathrm{mg} / \mathrm{L}$, as a cytokinin, were used for callus initiation, in addition to MS medium without growth regulators. Callus tissues were transferred to freshly prepared medium for proliferation. Each treatment contained at least 10 replicates and was repeated twice. Percentage of callus initiation, fresh weight of callus (g) and callus color and texture were recorded after eight weeks of culture.

\section{Elicitation}

Two elicitors; CH (OXOID, OXOID Limited, Hampshire, England) and YE (Sigma Aldrich) at concentrations of $0.5,1.0$ and $2.0 \mathrm{~g} / \mathrm{L}$, were added to the most favorable callus initiation medium for each type of explants, in order to improve the yield of kaempferol in the callus cultures. The control medium was made without elicitors. Growth of the callus tissue ( $\mathrm{g}$ fresh weight/jar) and kaempferol content (ng/g fresh weight) were measured. Callus tissues were oven dried at $35^{\circ} \mathrm{C}$ for $48 \mathrm{~h}$ for the quantification of kaempferol.

Extraction and Determination of Kaempferol Kaempferol was extracted from dry powdered samples, of callus, tissue of $S$. argel seedling's explants (stem, leaf and root) and the aerial parts of wild plant. Extraction was carried out with methanol (HPLC grade), till exhaustion. The filtered extract was dried under vacuum, and a known weight of each of the dried extracts was diluted with methanol $(1: 1 \mathrm{w} / \mathrm{v})$, into a round bottom flask, sonicated for five min. Four $\mathrm{ml}$ of conc. $\mathrm{HCl}$ (HPLC grade) was added and refluxed for $2.5 \mathrm{~h}$, cooled to room temp. A known quantity was transferred to a volumetric flask and completed to a known volume with $\mathrm{HPLC} \mathrm{H}_{2} \mathrm{O}$, then filtered over a $0.45 \mu \mathrm{m}$ syringe.

A standard solution of kaempferol $(3,5,7-$ trihydroxy-2-(4-hydroxyphenyl)-4H-1-

benzopyran-4-one; Sigma Aldrich) was prepared by dissolving kaempferol in acetonitrile $(2.0 \mathrm{mg}$ in $10 \mathrm{ml})$, sonicated for 
five min and filtered over a $0.45 \mu \mathrm{m}$ syringe. Standard solutions were prepared in the range of $50-2000 \mathrm{ng} / \mathrm{ml}$ by serial dilution method. Presence and content of kaempferol was determined in the different methanolic extracts by RP HPLC column (phenomenex, ODS-3,5 micron; 4.6×250) using; mobile phase $50 \%$ acetonitrile : water, $50 \mu \mathrm{l}$ injection volume, wave length of $365 \mathrm{~nm}, 1.5 \mathrm{ml} / \mathrm{min}$ flow rate, $40 \circ \mathrm{C}$ column temp, running time $4.5 \mathrm{~min}$ and PDA photodiode array detector. The retention time $\left(R_{t}=3.4 \mathrm{~min}\right)$ and online UV spectra of kaempferol was compared to those of the different samples.

\section{Statistical Analysis}

Experiments were subjected to the completely randomized design. Variance analysis of data was carried out using ANOVA for statistical analysis. The differences among means for all treatments were tested for significance at $5 \%$ level, by using Duncan's multiple range test (Duncan, 1955), as described by Snedecor and Cochran (1990). Means followed by the same letter are not significantly different.

\section{RESULTS AND DISCUSSION}

\section{Callus Initiation}

Hunderd percent of explants of $S$. argel produced callus on media containing all the growth regulators' combinations examined in the present study. As presented in Table 1, comparing the effect of different treatments on each explant type, the maximum callus fresh weight from seedlings' stem explants was obtained on MS medium containing 1.0 $\mathrm{mg} / \mathrm{L} \mathrm{2,4-D}$ and $0.5 \mathrm{mg} / \mathrm{L}$ KIN (Figure 1a), while, seedlings' leaf explants initiated callus of the highest biomass on MS medium containing $3.0 \mathrm{mg} / \mathrm{L} \mathrm{2,4-D}$ and $0.5 \mathrm{mg} / \mathrm{L} \mathrm{KIN}$ (Figure 1b). However, seedlings' root explants produced the maximum biomass of callus on MS medium containing $2.0 \mathrm{mg} / \mathrm{L} \mathrm{NAA}$ and 0.5 $\mathrm{mg} / \mathrm{L}$ KIN (Figure 1c). Comparing between explants, it was found that the ability of seedlings' leaf explants to produce and proliferate callus was higher than that of the other tested explants (Figure 1d), followed by the seedlings' root tissue. Moreover, 2,4-D was found to stimulate callus formation from both seedlings' stem and leaf explants, while seedlings' root explants responded better in the presence of NAA. The results show also that callus on the most favourable medium for each explant had a yellowish green color and a friable nodular desirable appearance.

In general, all explants had the capability to initiate callus, and this callus successfully proliferated on the same medium, which is promising for the production of high yield of tissue and consequently secondary metabolites. The capability to cultivate plant callus cells and produce homogeneity of an in vitro cell population, with large availability of material, and high rate of cell growth provide a valuable platform for the production of highvalue secondary metabolites and other substances of commercial interest (Moscatiello et al., 2013).

Effect of Elicitors on Callus Growth and Kaempferol Content

Two elicitors; $\mathrm{CH}$ and YE were added, separately, to the culture medium and their influence on the growth of callus cultures of $S$. argel and kampferol content was studied (Table 2). Generally, $\mathrm{CH}$ negatively affect callus biomass and had non-significant effect on kaempferol accumulation, compared to the control, except the concentration of $0.5 \mathrm{mg} / \mathrm{L}$, it increased the kaempferol production in callus derived from seedlings' root to 276.050 $\mathrm{ng} / \mathrm{g}$ dry weight, but this amount decreased with the increase of $\mathrm{CH}$ concentration. Treatment with YE also resulted in a lower callus biomass, compared to the control, for both callus derived from seedlings' stem and root, but it gave higher biomass of callus derived from seedlings' leaf over the control at concentrations of 0.5 and $1.0 \mathrm{mg} / \mathrm{L}$. The results in Table 2 show that there were significant differences in the content of kaempferol between the induced callus and the wild and seedlings' explants. The highest content of kaempferol was in callus derived from seedlings' stem on medium containing $2.0 \mathrm{mg} / \mathrm{L}$ YE (624.4356 ng/g dry weight) with a significant difference with all the other treatments, it enhanced kaempferol content to about 13 -fold over the control. Followed by 
Table 1. Callus initiation from seedlings' explants of $S$. argel on MS medium containing $0.5 \mathrm{mg} / \mathrm{L} \mathrm{KIN} \mathrm{in} \mathrm{addition} \mathrm{to} \mathrm{different} \mathrm{concentrations} \mathrm{of}$ 2,4-D or NAA (5 explants/jar) after 8 weeks of culture with $100 \%$ callus initiation on all tested growth regulators' combinations.

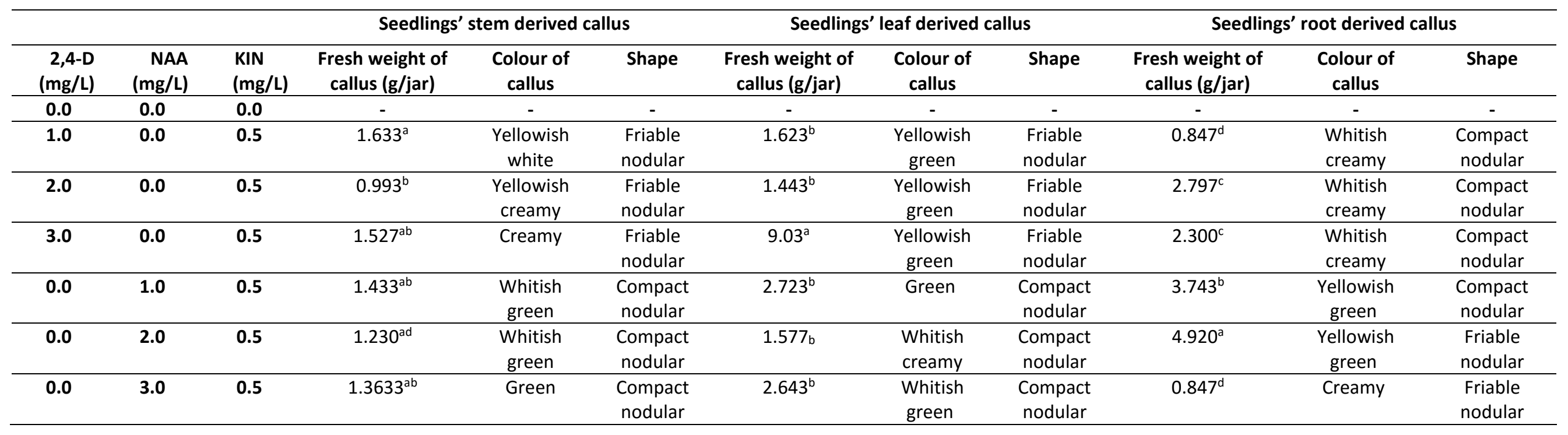


its content in the callus derived from the same explants treated with $0.5 \mathrm{~g} / \mathrm{L}$ YE $(307.211 \mathrm{ng} /$ $\mathrm{g}$ dry weight). However, the content of kaempferol was the highest in the wild plants (11885.125 ng/g dry weight) than in the seedlings' explants and in the callus. In general, the highest contents of kaempferol were in callus treated with YE. On the other hand, $\mathrm{CH}$ had the lowest effect on kaempferol accumulation, except for callus derived from seedlings' root at the concentration of $0.5 \mathrm{mg} / \mathrm{L}$. It is noticed that there is a reverse correlation between cell growth and kaempferol production. This represents a general complication found in in vitro secondary metabolites production (Maharik et al., 2009). Difference in contents of kaempferol between callus cultures and wild and seedlings' explants could be explained by the influence of overlapping growth regulators depending on the type and concentration of the used auxin and cytokinin. They could increase or decrease the amount of accumulated compound, due to the fact that growth regulators increase the absorption of minerals and accumulation of carbohydrates and amino acids (Besher et al., 2014).

Table 2. Fresh weight and kaempferol concentration in callus of $S$. argel after 8 weeks of culture on MS medium supplemented with the best callus induction medium for each explant type in addition to different concentrations of $\mathrm{CH}$ and $\mathrm{YE}$ as elicitors (5 explants/jar).

\begin{tabular}{|c|c|c|c|c|}
\hline Explant type & $\begin{array}{l}\mathrm{CH} \\
(\mathrm{g} / \mathrm{L})\end{array}$ & $\begin{array}{l}\text { YE } \\
\text { (g/L) }\end{array}$ & $\begin{array}{c}\text { Fresh weight } \\
\text { (g/jar) }\end{array}$ & $\begin{array}{l}\text { Kaempferol (ng/g } \\
\text { dry wt.) }\end{array}$ \\
\hline \multirow{7}{*}{$\begin{array}{l}\text { Callus derived from } \\
\text { seedlings' stem }{ }^{1}\end{array}$} & 0.0 & 0.0 & $3.593^{b}$ & $48.322^{e f}$ \\
\hline & 0.5 & 0.0 & $0.758^{k}$ & $11.561^{f}$ \\
\hline & 1.0 & 0.0 & $1.055^{\mathrm{ij}}$ & $55.758^{\mathrm{ef}}$ \\
\hline & 2.0 & 0.0 & $1.010^{\mathrm{ijk}}$ & $5.830^{f}$ \\
\hline & 0.0 & 0.5 & $1.190^{\mathrm{hi}}$ & $307.211^{b}$ \\
\hline & 0.0 & 1.0 & $1.705^{\mathrm{ef}}$ & $55.416^{\text {ef }}$ \\
\hline & 0.0 & 2.0 & $1.623^{\text {efg }}$ & $624.435^{a}$ \\
\hline \multirow{7}{*}{$\begin{array}{l}\text { Callus derived from } \\
\text { seedlings' leaf }\end{array}$} & 0.0 & 0.0 & $1.880^{\mathrm{e}}$ & $45.426^{\text {ef }}$ \\
\hline & 0.5 & 0.0 & $1.220^{\mathrm{hi}}$ & $47.814^{\text {ef }}$ \\
\hline & 1.0 & 0.0 & $1.520^{\mathrm{fg}}$ & $20.775^{f}$ \\
\hline & 2.0 & 0.0 & $1.215^{\mathrm{hi}}$ & $47.896^{\text {ef }}$ \\
\hline & 0.0 & 0.5 & $2.150^{d}$ & $15.065^{f}$ \\
\hline & 0.0 & 1.0 & $2.750^{c}$ & $62.354^{\text {ef }}$ \\
\hline & 0.0 & 2.0 & $1.820^{\mathrm{e}}$ & $102.946^{\text {de }}$ \\
\hline \multirow{7}{*}{$\begin{array}{l}\text { Callus derived from } \\
\text { seedlings' } \text { root }^{3}\end{array}$} & 0.0 & 0.0 & $4.055^{a}$ & $120.820^{d}$ \\
\hline & 0.5 & 0.0 & $0.875^{j k}$ & $276.050^{b}$ \\
\hline & 1.0 & 0.0 & $2.210^{d}$ & $7.143^{f}$ \\
\hline & 2.0 & 0.0 & $1.390^{\mathrm{gh}}$ & $57.700^{\text {ef }}$ \\
\hline & 0.0 & 0.5 & $0.812^{\mathrm{jk}}$ & Not detected \\
\hline & 0.0 & 1.0 & $2.585^{c}$ & $169.060^{c}$ \\
\hline & 0.0 & 2.0 & $2.715^{c}$ & $130.245^{d}$ \\
\hline Seedlings' stem & & & & 8790.520 \\
\hline Seedlings' leaf & & & & 4002.226 \\
\hline Seedlings' root & & & & 2061.622 \\
\hline Wild plant & & & & 11885.125 \\
\hline
\end{tabular}

${ }^{1}$ Callus derived from seedlings' stem cultured on MS medium+1.0 mg/L 2,4-D+0.5 mg/L kinetin supplemented with elicitors.

${ }^{2}$ Callus derived from seedlings' leaf cultured on MS medium+3.0 mg/L 2,4-D+0.5 mg/L kinetin supplemented with elicitors.

${ }^{3}$ Callus derived from seedlings' root cultured on MS medium $+2.0 \mathrm{mg} / \mathrm{L}$ NAA+0.5 mg/L kinetin supplemented with elicitors. 
Although, $\mathrm{CH}$ did not enhance kaempferol production in the present study, it is well known that $\mathrm{CH}$ is a source of calcium, several mico-nutrients, vitamins and a mixture of up to 18 amino acids. It was

investigated that $\mathrm{CH}$ contains some unknown growth promoting factors (Khaleda and AlForkan, 2006). Thus, the response of callus to a particular elicitor may vary between different plants and cell lines, therefore, it becomes crucial to determine the suitable type and concentration of elicitors for product optimization.

Currently, YE is commonly employed as a biotic elicitor for the induction and enhancement of secondary metabolites production. Reports suggest that YE is used as a supplement in order to promote plant growth, due to its high amino acid content (George et al., 2008). However, YE did not affect the fresh biomass of callus, the addition of $\mathrm{YE}$ into the culture medium increased kaempferol. This indicates that YE did not perform as nutrient supplement for the growth of callus. This might be the result of stress response of the callus to the accumulation of secondary metabolites due to the YE that acted as elicitor (Abraham et al., 2011).

Generally, elicitors could be used to enhance plant secondary-metabolite synthesis and could play an important role in biosynthetic pathways. Elicitiation is one of the important strategies to get better productivity of bioactive secondary products and to lower production costs. The secondary metabolites are released due to defense responses, which are triggered and activated by elicitors (Bharati and Bansal, 2014).

In conclusion, medicinal plants are the main source of secondary metabolites, which are industrially important as they constitute pharmaceutically important drugs. As a result, there is a huge demand for these plants, which are overexploited from their natural habitat. Therefore, plant tissue culture is being potentially used as an alternative strategy for production of secondary metabolites. Flavonoids are important secondary metabolites having immense medicinal properties ranging from anti-oxidant, anticancerous, anti-inflammatory etc. To enhance the rapid and controlled, continuous production of this class of compounds, in vitro culture strategies application would ensure large scale and stable production throughout the year, under controlled environmental conditions. The present study is a stepping stone in in vitro production of the flavonoid kaempferol from callus cultures of $S$. argel. Callus showed a potentiality for accumulation of kaempferol, especially from seedlings' stem explants.
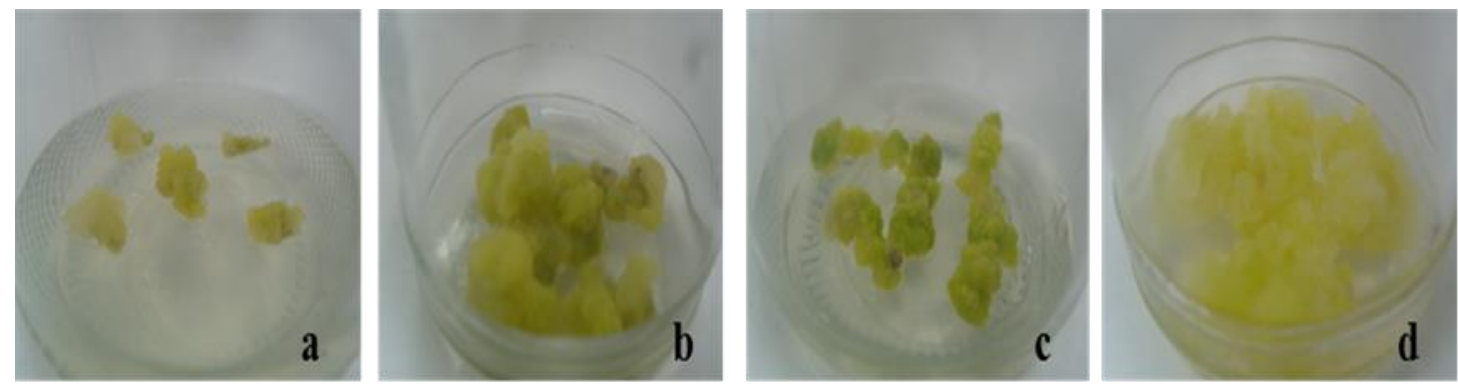

Figure 1. Callus of $S$. argel. (a) Callus derived from seedlings' stem cultured on MS medium+1.0 mg/L 2,4-D+0.5 mg/L kinetin. (b) Callus derived from seedlings' leaf on MS medium+3.0 mg/L 2,4-D+0.5 mg/L kinetin. (c)

Callus derived from seedlings' root on MS medium+2.0 mg/L NAA+0.5 mg/L kinetin. (d) Proliferated callus of S. argel. 


\section{REFERENCES}

Abd El-Hady, F.K. and Ouf, S.A. (1993). Fungitoxic effect of different substances from Solenostemma argel (Del.) Hyane on some shoot surface fungi. Zentralblatt fur Mikrobiologie, 148: 598-607.

Abd El-Hady, F.K.; Hegazi, A.G.; Ata, N.S. and El-Enbaawy, M. (1994a). Studies for determining antimicrobial activity of Solenostemma argel (Del.) Hayne. 1Extraction with methanol/water in different proportions. Qatar University Science Journal, 14: 138-142.

Abd El-Hady, F.K.; Hegazi, A.G.; Ata, N.S. and El-Enbaawy, M. (1994b). Studies for determining antimicrobial activity of Solenostemma argel (Del.) Hayne. 2. Extraction with chloroform/methanol in different proportions. Qatar University Science Journal; 14: SPEC/ISSUE, 143146.

Abraham, F.; Bhatt, A.; Keng, C.L.; Indrayanto, G. and Sulaiman, S.F. (2011). Effect of yeast extract and chitosan on shoot proliferation, morphology and antioxidant activity of Curcuma mangga in vitro plantlets. African Journal of Biotechnology, 10(40): 77877795.

Amariei, D.; Stanescu, U.; Gille, E. and Onisei, T. (1991). The biosynthetical capacity of the active principles of in vitro regenerated Solenostemma argel (Del.) Hayne callus and shoots. Revue Roumaine de Biologie. Serie de Biologie Vegetale, 36(1-2): 71-76.

Besher, S.; Al-Ammouri, Y. and Murshed R. (2014). Production of tropan alkaloids in the in vitro and callus cultures of Hyoscyamus aureus and their genetic stability assessment using ISSR markers. Physiology and Molecular Biology of Plants, 20(3): 343-349.

Bharati, A.J. and Bansal, Y.K. (2014). In vitro production of flavonoids: a review. World Journal of Pharmacy and Pharmaceutical Sciences, 3(6): 508-533.

Calderón-Montaño, J.M.; Burgos-Morón, E.; Pérez-Guerrero, C. and López-Lázaro, M. (2011). A review on the dietary flavonoid kaempferol. Mini-Reviews in Medicinal Chemistry, 11: 298-344.

Duncan, D.B. (1955). Multiple ranges and multiple "F" test. Biometrics, 1-42.

Ekiert, H. (2001). Medical plant biochemistry: the Apiaceae family as the example of rapid development. Pharmazie, 55: 561-570.

Ekiert, H. and Gomolka, E. (2000). Furanocoumarins in Pastinaca sativa $\mathrm{L}$. in vitro culture. Pharmazie, 55: 618620.

El-Askary, H. (2003). Pregnene glycoside and monoterpene derivative from Solenostemma argel Hayne. Bulletin of Faculty of Pharmacy, Cairo University, 41: 131-137.

El-Hadidi, M.N. and Fayed, A.A. (1994). Materials for excursion flora of Egypt (EFE). Tackholmia, 15: 118. El-Manar ElArabi Printhouse, Cairo.

El-Tahir, M.M.; El-Tayeb, I.B. and Shaddad, S.A.I. (2005). The pharmacological actions of the aqueous extract of the leaves of Solenostemma argel (Hayne) on isolated rabbit aortic strip and guinea pig atria. Journal of Animal and Veterinary Advances, 4(10): 831-834.

El-Tigani, S. and Ahmed, S.S. (2009). Solenostemma argel tissue culture for production of secondary metabolites. Journal of Genetic Engineering and Biotechnology, 7(1): 19-23.

George, M.A.; Hall, G. and Klerk J. (2008). The Components of Plant Tissue Culture Media I: Macro- and Micro-Nutrients. In: Plant Propagation by Tissue Culture, Springer, Netherlands, pp. 65-113

Hamed, A.I. (2001). New steroids from Solenostemma argel leaves. Fitoterapia, 72: 747-755.

Hanafi, N. and Mansour, S.Z. (2011). Antitumor efficacy of aqueous extract of Salenostemma argel leaves and/or gamma-radiation exposure against Ehrlich carcinoma in Swiss albino mice. International Journal of BioSciences and Technology, 4(1): 1-11. 
Hassan, H.A.; Hamed, A.I.; El-Emary, N.A.; Springuel, I.V.; Mitome, $H$. and Miyaoka, H. (2001). Pregnene derivatives from Solenostemma argel leaves. Phytochemistry, 57: 507.

Hegazi, A.A.; El-Enbaawy, M.; Abd El-Hady, F.K. and Ata, N.S. (1994). Studies for determining antimicrobial activity of Solenostemma argel (Del.) Hayne. 3Extraction with petroleum ether and ether. Journal of the Egyptian Veterinary Medical Association, 54(5): 401-411.

Hegazi, A.G.; Hanna, R.; Moharam, N.; ElHady, F.K.A.; El-Khaat, Z. and Kareem, K.M. (2006). Hepatotoxic and nephrotoxic effect of Solenostemma argel Del. Hayne. Egyptian Journal of Veterinary Sciences, 40: 19-31.

Heneidak, S.; Grayer, R.J.; Kite, G.C.; Simmonds, M.S.J. (2006). Flavonoid glycosides from Egyptian species of the tribe Asclepiadeae (Apocynaceae, subfamily Asclepiadoideae). Biochemical Systematics and Ecology, 34: 575.

Innocenti, G.; Dall'Acqua, S.; Sosa, S.; Altinier, G. and Della Loggia, R.J. (2005). Topical anti-inflammatory activity of Solenostemma argel leaves. Ethnopharmacollogy, 102: 307-310.

Irwin, K. (2008). Fruits, vegetables, teas may protect smokers from lung cancer. News Releases. UCLA. http://newsroom.ucla.edu/portal/u cla/fruits-vegetables-and-teas-may51210.aspx.

Jang, Y.J.; Kim, J.; Shim, J.; Kim, J.; Byun, S.; Oak, M.H.; Lee K.W. and Lee, H.J. (2011). Kaempferol attenuates 4hydroxynonenal-induced apoptosis in PC12 cells by directly inhibiting NADPH oxidase. Journal of Pharmacology and Experimental Therapeutics, 337(3): 747-54.

Kamel, M.S. (2003). Acylated phenolic glycosides from Solenostemma argel. Phytochemistry, 62: 1247-1250.

Kamel, M.S.; Ohtani, K.; Hasanain, H.A.; Mohamed, M.H.; Kasai, R. and Yamasaki, K. (2000). Monoterpene and pregnane glucosides from
Solenostemma argel. Phytochemistry, 53: 937-940.

Khaleda, L. and Al-Forkan, M. (2006). Stimulatory effects of casein hydrolysate and proline in in vitro callus induction and plant regeneration from five deepwater rice (Oryza sativa L.). Biotechnology, 5(3): 379-384.

Khalid, S.A.; Kalaflla, E.B. and Mohamed, O.Y. (1992). The flavonoids of Solanostemma argel and their antispasmodic activity. Planta Medica, 58: 7, A651.

Konam, K.; Chinta R.; Lukaraju P.S.; Bonthu M.G. and Pottabathula, H.P. (2012). Bioanalytical method development and reaction rate study of kaempferol in albino rats plasma using RP-HPLC method. International Journal of Biological and Pharmaceutical Research, 3(2): 197-203.

Maharik, N.; Elgengaihy, S. and Taha, H. (2009). Anthocyanin production in callus cultures of Crataegus Sinaica Boiss. International Journal of Academic Research, 1(1): 30-34.

Marsik, P.; Langhansova, L.; Dvorakova, M.; Cigler, P.; Hruby, M. and Vanek, T. (2014). Increased ginsenosides production by elicitation of in vitro cultivated Panax ginseng adventitious roots. Medicinal and Aromatic Plants, 3 (1).

Moscatiello, R.; Baldan, B. and Navazio, L. (2013). Plant Suspension Cultures. In: Frans, J.M. (Ed.). Plant Mineral Nutrients Series: Methods in Molecular Biology, 953: 77-93. Humana Press, Springer.

Murashige, T. and Skoog, F. (1962). A revised medium for rapid growth and bioassays with tobacco tissue cultures. Physiologia Plantarum, 15:473-497.

Nassr-Allah, A.A.; Aboul-Enein, A.M.; AboulEnein, K.M.; Lightfoot, D.A.; Cocchetto, A. and El-Shemy, H.A. (2009). Anticancer and anti-oxidant activity of some Egyptian medicinal plants. Journal of Medicinal Plants Research, 3(10): 799808. 
Perrone, A.; Plaza, A.; Ercolino, S.F.; Hamed, A.I.; Parente, L.; Pizza, C. and Piacente, S. (2006). 14, 15-secopregnane derivatives from the leaves of Solenostemma argel. Journal of Natural Products, 69: 50-54.

Perrone, A., Plaza, A.; Hamed A.; Pizza C. and Piacente, S. (2008). Solenostemma argel: A rich source of very unusual pregnane and 14, 15- secopregnane glycosides with antiproliferative activity. Current Organic Chemistry, 12.

Plaza, A.; Bifulco, G.; Hamed, A.; Pizza, C. and Piacente, S. (2003). Argeloside A and B, two novel 14, 15-secopregnane glycosides from Solenostemma argel. Tetrahedron Letters, 44: 8553-8558.

Plaza, A.; Piacente, S.; Perrone, A.; Hamed, A.; Pizza, C. and Bifulco, G. (2004). Stemmosides $C$ and $D$, two novel unusual pregnane glycosides from Solenostemma argel: structural elucidation and configurational study by a combined NMR-quantum mechanical strategy. Tetrahedron, 60: 12201-12209.

Plaza, A.; Perrone, A.; Balestrieri, M.L.; Felice, F.; Balestrieri, C.; Hamed, A.; Pizza, C. and Piacente, S. (2005a). New unusual pregnane glycosides with antiproliferative activity from
Solenostemma argel. Steroids, 70: 594603.

Plaza, A.; Perrone, A.; Balestrieri, C.; Balestrieri, M.L.; Bifulco, G.; Carbone V.; Hamed, A.; Pizza, C. and Piacente, S. (2005b). New antiproliferative 14,15secopregnane glycosides from Solenostemma argel. Tetrahedron, 61: 7470-7480.

Shafek, R.E.; Shafik, N.H. and Michael, H.N. (2012). Antibacterial and antioxidant activities of two new kaempferol glycosides isolated from Solenestemma argel stem extract. Asian Journal of Plant Sciences, 11: 143-147.

Shawkat, T. (1997). Patent fast alert USA05648089, July 15.

Snedecor, G.W. and Cochran, W.G. (1990). Statical Methods. $8^{\text {th }}$ Edition. Iowa State University Press, Ames, lowa, USA.

Täckholm, V. (1974). Students Flora of Egypt, Cairo University Press, Cairo, p. 410.

Tharib, S.M.; El Migirab, S. and Veitch, G.B.A. (1986). A preliminary investigation of the potential antimicrobial activity of Solenostemma argel. International Journal of Crude Drug Research, 24(2): 101-104. 